\title{
Influence of packaging materials on purchase of food products by the consumers
}

Shivabasappa and H.S. Ravikumar Patil

Received : 03.07.2020; Accepted : 26.09 .2020

See end of the Paper for authors' affiliation

Correspondence to :

Shivabasappa

Department of Agricultural

Engineering, College of

Agriculture (U.A.S.), Hassan

(Karnataka) India

Email: shivukandkur424@

gmail.com; shivukandkur2020 @ gmail.com
- KEY WORDS : Influence packaging materials, Food products

- HOW TO CITE THIS PAPER : Shivabasappa and Ravikumar Patil, H.S. (2020). Influence of packaging materials on purchase of food products by the consumers. Internat. J. Agric. Engg., 13(2) : 272-275, DOI: 10.15740/HAS/IJAE/13.2/272-275. Copyright@2020: Hind Agri-Horticultural Society. 